\title{
Peran Kecerdasan Emosional dan Tingkat Ketergantungan Nikotin pada Niat Berhenti Merokok
}

\section{The Influence of Emotional Intelligence and Nicotine Dependence Level on Smoking Cessation Intention}

\author{
Dewi Masithah $^{1^{*}}$, Oedojo Soedirham ${ }^{2}$, Rita S. Triyoga ${ }^{2}$ \\ ${ }^{1}$ Post Graduated Student of Health Promotion and Behavior Science Department, Public \\ Health Faculty, Airlangga University \\ ${ }^{2}$ Staff of Health Promotion and Behavior Science Department, Public Health Faculty, \\ Airlangga University \\ (*demas_1981@yahoo.com)
}

\begin{abstract}
ABSTRAK
Niat berhenti merokok merupakan faktor motivasi yang mempengaruhi perilaku. Niat berhenti merokok dipengaruhi oleh sikap terhadap perilaku berhenti merokok, norma subjektif, dan persepsi kontrol perilaku. Penelitian ini bertujuan untuk menganalisis pengaruh kecerdasan emosional dan tingkat ketergantungan nikotin terhadap niat berhenti merokok. Studi ini merupakan penelitian observasional analitik dengan rancangan cross sectional dan menggunakan pendekatan kuantitatif. Populasi penelitian ini adalah mahasiswa Perguruan Tinggi Negeri (PTN) di Madura berjenis kelamin laki-laki dan merokok. Pengambilan sampel menggunakan metode proportionate stratified random sampling dengan besar sampel 290 orang. Hasil penelitian ini yaitu kecerdasan emosional berpengaruh terhadap niat berhenti merokok melalui sikap terhadap perilaku berhenti merokok dan norma subjektif. Tingkat ketergantungan nikotin berpengaruh terhadap niat berhenti merokok melalui sikap terhadap perilaku berhenti merokok, norma subjektif, dan persepsi kontrol perilaku. Kesimpulan dari penelitian ini adalah tingkat ketergantungan nikotin lebih berpengaruh terhadap niat berhenti merokok daripada kecerdasan emosional. Kata kunci : Niat berhenti merokok, kecerdasan emosional
\end{abstract}

\section{ABSTRACT}

Smoking cessation intention is a motivating factor that influence to smoking cessation behavior. Smoking cessation intention is influenced by attitude toward smoking cessation behavior, subjective norm, and perceived behavior control. This research aims to analyze the influence of emotional intelligence and nicotine dependence level on smoking cessation intention. This research was obesevational analytic study with cross sectional design and used a quantitative approach. The population of this study were male smoker college student of state university in Madura. The sampling method used proportionate stratified random sampling with sample size 290 college student. The result of this study are emotional intelligence influenced smoking cessation intention trough attitude toward smoking cessation behavior and subjective norm. Nicotine dependence level influenced smoking cessation intention trough attitude toward smoking cessation, subjective norm, and perceived behavior control. The conclusion of this study was nicotine dependence level has more influence on smoking cessation intention than emotional intelligence.

Keyword : Smoking cessation intention, emotional intelligence 


\section{PENDAHULUAN}

Merokok adalah perilaku yang memicu berbagai macam penyakit. Merokok berhubungan dengan berbagai penyakit kanker, penyakit paruparu, penyakit jantung koroner, dan lain-lain. Jumlah perokok berusia 15 tahun dan berjenis kelamin laki-laki terbanyak di dunia terdapat di China dengan jumlah perokok 264 juta, diikuti oleh India dengan jumlah 106 juta orang, dan Indonesia dengan jumlah 50,6 juta orang. ${ }^{1}$ Menurut Riset Kesehatan Dasar (Riskesdas) tahun 2007 prevalensi pengguna tembakau adalah $34,2 \%$, Riskesdas tahun 2010 sebesar 34,7\%, dan Riskesdas 2013 sebesar $36,3 \%$. Hal ini menunjukkan tren kenaikan prevalensi pengguna tembakau. $^{2}$

Setiap tahunnya lebih dari 7 juta orang di dunia meninggal karena penggunaan tembakau. Dari jumlah tersebut, $80 \%$ kematian terjadi di negara berpenghasilan menengah dan rendah., ${ }^{3,4}$ Penderita kanker akibat penyakit merokok di Indonesia pada tahun 2012 adalah sebanyak 43.578 orang. Jumlah ini merupakan yang terbesar diantara negara-negara di kawasan Asia Tenggara. Sebanyak $53,3 \%$ dari penderita tersebut menderita kanker paru-paru. ${ }^{5}$

Global Adult Tobacco Survey (GATS) tahun 2011 menunjukkan hampir 50\% perokok di Indonesia memiliki keinginan untuk berhenti merokok. Survei awal yang dilakukan di tempat penelitian menunjukkan bahwa sekitar $66 \%$ perokok ingin berhenti merokok. ${ }^{6}$ Berhenti merokok merupakan hal yang tidak mudah dilakukan. Berhenti merokok menyebabkan gejala fisik dan psikis yang tidak menyenangkan. Gejala fisik yang terasa antara lain dada terasa sesak, jantung berdebar, dan berkeringat. Gejala psikis yang terjadi antara lain merasa sedih, gelisah, marah, susah konsentrasi, dan mudah tersinggung. ${ }^{7}$

Berhenti merokok memerlukan niat yang kuat. Niat mencerminkan kesiapan seseorang untuk berperilaku. Apabila seorang perokok berniat untuk berhenti merokok, maka orang tersebut akan menunjukkan kesiapannya dan mencurahkan energinya untuk berhenti merokok. ${ }^{8}$ Menurut Theory of Planned Behavior (TPB) niat dipengaruhi oleh sikap terhadap perilaku, norma subjektif, dan persepsi kontrol perilaku. Sikap menggambarkan kenyamanan atau ketidaknyamanan sebuah perilaku dan baik atau buruknya sebuah perilaku sebagai bentuk evaluasi individu berdasarkan perasaannya. Norma subjektif berkaitan dengan keyakinan normatif seseorang terhadap sebuah perilaku, apa yang individu harapkan dari suatu perilaku, dan apakah kebanyakan orang melakukan perilaku tersebut, sehingga muncul perasaan setuju atau tidak setuju terhadap perilaku itu. Persepsi kontrol perilaku menggambarkan tentang perasaan seseorang, apakah orang tersebut mampu atau tidak mampu melakukan perilaku tersebut. ${ }^{9,10,11}$

Ciri kepribadian dan variabel individu lainnya mempengaruhi sikap terhadap perilaku berhenti merokok, norma subjektif, dan persepsi kontrol perilaku. Kecerdasan emosional dan tingkat ketergantungan nikotin merupakan salah satu ciri kepribadian dan variabel individu lainnya yang dapat mempengaruhi sikap terhadap perilaku, norma subjektif, dan persepsi kontrol perilaku. ${ }^{10}$ Kecerdasan emosional adalah kemampuan seseorang untuk mengontrol diri, mempunyai toleransi ketika menghadapi suatu masalah, dapat mengelola suasana hati, keterampilan berempati, dan menjalin hubungan dengan orang lain. ${ }^{12}$ Ketergantungan nikotin adalah suatu kondisi dimana tubuh membutuhkan nikotin secara terus menerus. Nikotin merangsang susunan saraf pusat sehingga menimbulkan rasa senang, gembira, meningkatkan performa, dan kecemasan. ${ }^{7}$ Studi ini bertujuan untuk menganalisis pengaruh kecerdasan emosional dan tingkat ketergantungan nikotin terhadap niat berhenti merokok.

\section{BAHAN DAN METODE}

Studi ini adalah studi observasional analitik dengan rancang bangun cross sectional dan pendekatan kuantitatif. Lokasi penelitian berada di Perguruan Tinggi Negeri di Madura. Waktu penelitian yaitu mulai bulan Desember 2017 sampai Juni 2018. Populasi pada studi ini adalah mahasiswa laki-laki yang merokok. Sampel diambil dengan metode proportionate stratified random sampling dengan besar sampel 290 orang. Kriteria inklusi untuk pengambilan sampel adalah mahasiswa laki-laki, perokok, dan berusia lebih dari 18 tahun. Variabel dalam penelitian ini adalah kecerdasan emosional, tingkat ketergantungan nikotin, sikap terhadap perilaku berhenti merokok, norma subjektif, persepsi kontrol perilaku, dan niat ber- 
henti merokok. Instrumen yang digunakan untuk mengukur semua variabel tersebut adalah kuesioner. Teknik analisis data yang digunakan dalam studi adalah analisis regresi linier multipel.

\section{HASIL}

Mayoritas responden pada studi ini berusia 20-21 tahun dengan jumlah 151 (52,0\%). Sepertiga responden merupakan mahasiswa angkatan 2017 (30,3\%) (Tabel 1). Kecerdasan emosional tidak signifikan pengaruhnya terhadap sikap terhadap perilaku berhenti merokok ( $p>0,05$ ). Tingkat ketergantungan nikotin signifikan pengaruhnya terhadap sikap terhadap perilaku berhenti merokok $(p<0,05)$. Pengaruh tingkat ketergantungan nikotin terhadap sikap terhadap perilaku berhenti merokok adalah pengaruh negatif. Hal ini berarti bahwa semakin rendah tingkat ketergantungan nikotin, maka sikap terhadap perilaku berhenti merokok semakin positif. Dengan kata lain, semakin tinggi tingkat ketergantungan nikotin maka sikap terhadap perilaku berhenti merokok semakin negatif.

Kecerdasan emosional dan tingkat ketergantungan nikotin memiliki pengaruh signifikan terhadap norma subjektif $(\mathrm{p}<0,05)$. Pengaruh kecerdasan emosional terhadap norma subjektif adalah pengaruh positif. Hal ini berarti bahwa semakin tinggi tingkat kecerdasan emosional maka semakin tinggi norma subjektif. Begitu juga sebaliknya, semakin rendah tingkat kecerdasan emosional maka semakin rendah norma subjektif. Pengaruh tingkat ketergantungan nikotin terhadap norma subjektif adalah pengaruh negatif. Hal ini berarti bahwa semakin rendah tingkat ketergantungan nikotin, maka norma subjektif semakin

Tabel 1. Gambaran Karakteristik Responden

\begin{tabular}{ccc}
\hline Karakteristik & $\mathbf{n = 2 9 0}$ & $\mathbf{\%}$ \\
\hline Usia (tahun) & & \\
$18-19$ & 69 & 23,8 \\
$20-21$ & 151 & 52,0 \\
$22-23$ & 67 & 23,1 \\
$>23$ & 3 & 1,0 \\
Tahun Masuk & & \\
2014 & 63 & 21,7 \\
2015 & 72 & 24,8 \\
2016 & 67 & 23,1 \\
2017 & 88 & 30,3 \\
\hline
\end{tabular}

Sumber: Data Primer, 2018
Tabel 2. Analisis Pengaruh Sikap terhadap Perilaku Berhenti Merokok, Norma Subjektif, dan Persepsi Kontrol Perilaku Terhadap Niat Berhenti Merokok

\begin{tabular}{lccc}
\hline \multicolumn{1}{c}{ Variabel } & b & p & Keterangan \\
\hline $\begin{array}{l}\text { Sikap terhadap } \\
\text { perilaku berhenti } \\
\text { merokok }\end{array}$ & 0,473 & 0,000 & Signifikan \\
Norma subjektif & 0,387 & 0,000 & Signifikan \\
$\begin{array}{l}\text { Pesepsi kontrol } \\
\text { perilaku }\end{array}$ & 0,176 & 0,000 & Signifikan \\
\hline
\end{tabular}

Sumber: Data Primer, 2018

tinggi. Dengan kata lain, semakin tinggi tingkat ketergantungan nikotin maka norma subjektif semakin rendah.

Kecerdasan emosional pengaruhnya tidak signifikan terhadap persepsi kontrol perilaku $(p>0,05)$. Tingkat ketergantungan nikotin memiliki pengaruh signifikan terhadap persepsi kontrol perilaku $(p<0,05)$. Pengaruh tingkat ketergantungan nikotin terhadap persepsi kontrol perilaku adalah pengaruh negatif. Semakin rendah tingkat ketergantungan nikotin, maka persepsi kontrol perilaku semakin tinggi. Dengan kata lain, kian tinggi tingkat ketergantungan nikotin maka persepsi kontrol perilaku kian rendah.

Sikap terhadap perilaku berhenti merokok, norma subjektif, dan persepsi kontrol perilaku pengaruhnya signifikan terhadap niat berhenti merokok. Ketiga variabel ini pengaruhnya positif terhadap niat berhenti merokok. Semakin positif sikap terhadap perilaku berhenti merokok maka semakin baik niat berhenti merokok. Kian tinggi norma subjektif maka kian baik niat berhenti merokok. Kian tinggi persepsi kontrol perilaku kian baik niat berhenti merokok. Begitu juga sebaliknya (Tabel 2).

\section{PEMBAHASAN}

Kecerdasan emosional adalah ketrampilan atau keahlian untuk memahami, mengatur emosi, menilai emosi diri dan orang lain, serta memanfaatkan emosi untuk mendukung kemampuan berpikir yang lebih baik. ${ }^{13}$ Dalam penelitian ini, kecerdasan emosional tidak mempengaruhi sikap terhadap perilaku berhenti merokok. Hal ini berarti bahwa kecerdasan emosional tidak berpengaruh 
pada niat berhenti merokok melalui sikap terhadap perilaku berhenti merokok. Temuan ini tidak sama dengan temuan pada penelitian Lizam et al yang menunjukkan bahwa kecerdasan emosional berhubungan dengan sikap positif terhadap perilaku berhenti merokok. Pelatihan kecerdasan emosional dapat menambah sikap positif terhadap perilaku berhenti merokok. Dengan meningkatnya kecerdasan emosional, komunikasi intrapersonal seseorang akan lebih baik dan sikap positif terhadap perilaku berhenti merokok semakin bertambah. ${ }^{14}$

Kecerdasan emosional mempengaruhi norma subjektif. Hal ini berarti bahwa kecerdasan emosional mempengaruhi niat berhenti merokok melalui norma subjektif. Norma subjektif merupakan norma responden yang berkaitan dengan keyakinan normatif seseorang terhadap sebuah perilaku apakah kebanyakan orang melakukan hal ini. Norma masyarakat di suatu daerah dapat mempengaruhi norma subjektif seseorang. ${ }^{8}$ Responden dalam penelitian ini merupakan mahasiswa yang lebih banyak bersosialisasi dengan teman sebaya (peer groups). Teman sebaya yang merokok dapat menyebabkan seseorang ikut merokok. ${ }^{15}$ Tekanan dari keluarga merupakan komponen yang dapat mempengaruhi seseorang untuk berhenti merokok. Keluarga dan orang sekitar merupakan alasan perokok untuk berhenti merokok. Perokok merasa tidak nyaman dan merasa bersalah bila harus merokok di depan keluarga mereka. ${ }^{16}$ Seseorang dengan kecerdasan emosional tinggi lebih baik dalam mengenali dan mengapresiasi emosi yang dialami oleh orang lain. Perokok biasa merokok karena stres atau emosi negatif lainnya. Seorang perokok dengan tingkat kecerdasan emosional tinggi lebih baik dalam mengolah rasa stres dan emosi negatif sehingga dapat mengurangi keinginan untuk merokok. ${ }^{17}$

Kecerdasan emosional tidak berpengaruh terhadap persepsi kontrol perilaku secara signifikan. Hal ini berarti kecerdasan emosional tidak berpengaruh terhadap niat berhenti merokok melalui persepsi kontrol perilaku. Persepsi kontrol perilaku merupakan sejauh mana seorang individu mengontrol keinginannya untuk berhenti merokok. Kecerdasan emosional memiliki daya protektif terhadap perilaku merokok. Kian tinggi tingkat kecerdasan yang dimiliki seseorang, maka kian mampu menerima perasaan jika tidak merokok dirinya akan memiliki sedikit teman atau perasaan bahwa mereka tidak diinginkan menjadi bagian dari kelompok. ${ }^{18}$

Nikotin merupakan alkaloid yang terdapat dalam tembakau. Nikotin merupakan komponen yang menyebabkan ketergantungan. Nikotin dalam asap rokok terhisap melalui hidung, kemudian masuk ke paru-paru, dan diabsorbsi di alveoli paru. Nikotin dengan mudah diserap epitel paru-paru, mukosa hidung, dan mulut. Nikotin terdistribusi ke beberapa jaringan lain di tubuh seperti hati, ginjal, dan otak. Selain itu nikotin juga ditemukan dalam cairan lambung, air liur, air susu ibu, dan cairan amnion. ${ }^{3}$ Dalam sistem saraf pusat, nikotin mengubah cara kerja otak dan menyebabkan tubuh meminta lebih. ${ }^{7}$

Tingkat ketergantungan nikotin merupakan suatu tingkatan kondisi dimana seseorang menginginkan nikotin secara terus menerus. Tingkat ketergantungan nikotin berpengaruh signifikan terhadap sikap terhadap perilaku berhenti merokok, norma subjektif, dan persepsi kontrol perilaku. Hal ini berarti bahwa tingkat ketergantungan nikotin berpengaruhi pada niat berhenti merokok melalui sikap terhadap perilaku berhenti merokok, norma subjektif, dan persepsi kontrol perilaku.

Vidal et al., menyatakan bahwa niat berhenti merokok berhubungan dengan tingkat ketergantungan nikotin. Tingkat ketergantungan nikotin berhubungan dengan motivasi yang rendah untuk berhenti merokok. Seseorang dengan tingkat ketergantungan nikotin yang tinggi mempunyai motivasi berhenti merokok lebih rendah daripada seseorang dengan tingkat ketergantungan nikotin yang lebih rendah. ${ }^{19}$ Motivasi yang rendah ini dapat terjadi ketika individu beberapa kali mencoba berhenti merokok tetapi tidak berhasil. Semakin banyak individu mengalami kegagalan untuk berhenti merokok, maka niat untuk berhenti merokok semakin rendah. ${ }^{20}$

Sebagian besar perokok yang ingin menyetop merokok mengalami kesulitan berhenti merokok karena ketergantungan nikotin.. Perokok yang mencoba berhenti merokok dapat mengalami rasa cemas, marah, gelisah, susah konsentrasi, nafsu makan meningkat, mood depresi, dan insomnia. ${ }^{7}$ Rasa tidak nyaman ini yang menyebabkan pero- 
kok susah untuk berhenti merokok. ${ }^{21}$ Tingkat ketergantungan nikotin yang tinggi identik dengan kadar nikotin yang lebih tinggi dalam tubuh. Pada individu dengan kadar nikotin yang lebih tinggi, proses pengeluaran nikotin dari tubuh membutuhkan waktu yang lebih lama dibanding dengan individu dengan kadar nikotin yang lebih rendah. ${ }^{3}$

Sikap seseorang dipengaruhi oleh berbagai latar belakang. Latar belakang ini dapat berasal dari faktor perseorangan, sosial dan informasi. Faktor perseorangan antara lain kepribadian, emosi, dan kecerdasan. Faktor sosial antara lain usia, jenis kelamin, pendidikan, dan agama. Faktor informasi antara lain pengetahuan, pengalaman, dan paparan media. Sikap memiliki aspek pemikiran (kognisi), perasaan (afeksi), dan predisposisi tindakan (konasi). Sikap terhadap perilaku berhenti merokok merupakan variabel yang berpengaruh secara signifikan terhadap niat berhenti merokok. ${ }^{11}$

Norma subjektif dapat merupakan suatu tekanan sosial terhadap individu untuk melakukan suatu perilaku. Adanya tekanan sosial untuk berhenti merokok dapat merubah perilaku. Tekanan sosial untuk berhenti merokok ini misalnya kampanye untuk berhenti merokok atau pendapat tokoh penting atau berpengaruh untuk berhenti merokok. ${ }^{22}$ Rise mengungkapkan bahwa norma subjektif lebih kuat mempengaruhi niat bila digunakan pada masyarakat yang masih menjunjung nilai-nilai kekeluargaan dan sosial. ${ }^{23}$ Dalam penelitian ini, norma subjektif merupakan variabel yang berpengaruh secara signifikan terhadap niat berhenti merokok.

Persepsi kontrol perilaku menggambarkan perasaan seseorang apakah seseorang mampu atau tidak mampu melakukan perilaku tersebut. Persepsi kontrol merupakan prediktor yang kuat untuk niat. ${ }^{8}$ Persepsi kontrol perilaku yang rendah dapat diakibatkan oleh kurangnya keterampilan atau adanya hambatan lingkungan terhadap individu. ${ }^{24}$ Dalam konteks gaya hidup atau perilaku, persepsi kontrol perilaku dapat menyesuaikan dengan besar kecilnya niat. ${ }^{25}$

Banyak penelitian terdahulu yang menyatakan bahwa sikap, norma subjektif, dan persepsi kontrol perilaku merupakan prediktor yang kuat terhadap niat berhenti merokok. Asare menyatakan bahwa sikap, norma subjektif, dan persepsi kontrol perilaku merupakan prediktor yang signifikan terhadap niat memakai kondom pada mahasiswa. ${ }^{26}$ Suphat menyatakan bahwa sikap, norma subjektif, dan persepsi kontrol perilaku mempengaruhi niat untuk melakukan deteksi dini kanker serviks secara signifikan. ${ }^{27}$ Lestarina menyatakan bahwa sikap, norma subjektif dan persepsi kontrol perilaku memiliki pengaruh signifikan terhadap niat untuk memeriksakan gula darah secara teratur pada pasien diabetes melitus type $2 .{ }^{28}$

\section{KESIMPULAN DAN SARAN}

Dari hasil analisis diatas dapat ditarik kesimpulan bahwa kecerdasan emosional berpengaruh terhadap niat berhenti merokok melalui norma subjektif sedangkan tingkat ketergantungan nikotin berpengaruh terhadap niat berhenti merokok melalui sikap terhadap perilaku berhenti merokok, norma subjektif, dan persepsi kontrol perilaku. Prediktor yang lebih signifikan dalam mempengaruhi niat berhenti merokok adalah tingkat ketergantungan nikotin. Untuk meningkatkan kecerdasan emosional, pelatihan dapat dilakukan. Pelatihan kecerdasan emosional dapat meningkatkan sikap positif terhadap perilaku berhenti merokok. Untuk menurunkan tingkat ketergantungan nikotin diperlukan kerjasama dengan instansi kesehatan seperti puskesmas maupun rumah sakit. Konsultasi lebih lanjut pada tenaga medis diperlukan untuk menurunkan tingkat ketergantungan nikotin.

\section{DAFTAR PUSTAKA}

1. Eriksen, M., Mackay, J., Schluger, N., Gomeshtapeh, FI., \& Drope, J. The Tobacco Atlas 5th Edition. American Cancer Society : USA; 2015 .

2. Kementerian Kesehatan RI. Riset Kesehatan Dasar 2013. Badan Penelitian dan Pengembangan Kesehatan Kementerian Kesehatan RI : Jakarta; 2013.

3. U.S. Department of Health and Human Services. The Health Consequences Of Smoking-50 Years Of Progress : A Report Of The Surgeon General. U.S. Department of Health and Human Services : Rockville, USA; 2014.

4. World Health Organization (WHO). Tobacco Threathens Us All: Say No To Tobacco Protect Health, Reduce Poverty and Promote Development. WHO : Switzerland; 2017. 
5. Kristina, SA., Endarti, D., \& Thavorncharoensap, M. Burden of Cancer Attributable to Tobacco Smoking in Member Countries of The Association of Southeast Asian Nations (ASEAN), 2012. Cancer Epidemiology. 2016;44:84-90.

6. World Health Organization (WHO). Global Adult Tobacco Survey : Indonesia Report 2011. WHO : Jakarta; 2012.

7. Kaplan, H.I., Sadock, B.J., \& Grebb, J.A. Sinopsis Psikiatri Ilmu Pengetahuan Perilaku Psikiatri Klinis. Binarupa Aksara : Jakarta; 2010.

8. Ajzen, I. Behavioral Interventions Based on The Theory of Planned Behavior. 2006. Diakses online dari http://people.umass.edu/ aizen/pdf/tpb.intervention.pdf pada 20 Maret 2018.

9. Ajzen, I. The Theory of Planned Behavior. Organizational Behavior and Human Decision Processes. 1991;50(2):179-211.

10. Glanz, K. Rimer, BK. Viswanath, K. Health Behavior and Health Education, Theory, Research, and Practice. Jossey-Bass : USA;2008.

11. Lange, PAM., Kruglanski, AW., \& Higgins, ET. Handbook of Theories of Social Psychology. Sage : London, UK; 2012.

12. Goleman, D. Kecerdasan Emosional. PT. Gramedia Pustaka Utama : Jakarta; 2002.

13. Mayer, JD. \& Salovey, P. What is emotional intelligence? In P. Salovey \& Sluyter (Eds), Emotional Development and Emotional Intelligence : Education Implication. Basic book : New York; 1997.

14. Lizam, TC., Prabandari, YS., \& Kumara, A. Meningkatkan Sikap Positif terhadap Perilaku Tidak Merokok dan Kecenderungan Untuk Berhenti Merokok Melalui Pelatihan. Berita Kedokteran Masyarakat. 2009;2(2): 74-81.

15. Rachmat,M., Thaha, RM., \& Syafar, M. Perilaku Merokok Remaja Sekolah Menengah Pertama. Jurnal Kesehatan Masyarakat Nasional, 2013;7(11):502-508.

16. Mayer, JD., Caruso, DR., \& Salovey, P. The Ability Model of Emotional Intelligence : Principles and Updates. Emotion Review. 2016;8(4):290-300.

17. Trinidad, DR., \& Johnson, CA. The Asso- ciation Between Emotional Intelligence and Early Adolescent Tobacco and Alcohol Use. Personality and individual differences. 2002; 32:95-105

18. Vidal, PM., Cerveira, JM., Paccaud, F., Waeber, G., Vollenweider, P., \& Cornuz, J. Prevalence and Factors Associated with Difficulty and Intention to Quit Smoking In Switzerland. BMC Public Heath. 2011;11:227.

19. Lee, CW., \& Kahende, J. Factors Associated with Successful Smoking Cessation in the United Stated, 2000. American Journal of Public Health. 2007;97(8):1503-1509.

20. Rajamaki, H., Katajavuori, N., Jarvinen, P., Hakuli, T., Terasalmi, E. \& Pietila, K. A Qualitative Study of the Difficulties of Smoking Cessation : Healthcare Professionals and Smokers Point of View. Pharmacy World \& Science. 2002;2(6):240-246

21. De Wilde, K., Maes, L., Boudrez, H., Tency, I., Temmerman, M., \& Clays, E. (2017). Analysis of Smoking Cessation Beliefs in Pregnant Smokers and Ex-Smokers Using The Theory of Planned Behavior. Journal of Public Health. 2017;25(3):267-274.

22. Rise, J., Kovac, V., Kraft, P., \& Moan, IS. Predicting the Intention to Quit Smoking and Quitting Behavior : Extending the Theory of Planned Behavior. British Journal of Health Psychology. 2008;13(2):291-310.

23. Martinez, LS. \& Lewis, N. The Moderated Influence of Perceived Behavior Control on Intentions among the General US Population: Implications for Public Communication Campaigns. Journal of Health Community. 2016; 21(9):1006-1015

24. Yzer,MC. The Integrated Model of Behavior as a Tool for Designing Health Messages: Theory and Practice. In H. Cho (Ed). Designing Messages For Health Communication Campaigns : Theory and Practice. Thousand Oaks, CA. $2012: 21-40$.

25. Asare, M. Using the Theory of Planned Behavior to Determine the Condom Use Behavior Among College Student. American Journal of Health Study. 2015;30(1):43-50

26. Sulpat, E. Pengaruh Karakteristik Sikap, Norma Subjektif, \& Kontrol Perilaku WUS terhadap Niat Deteksi Dini Kanker Serviks Di 
Puskesmas Alun-Alun Kabupaten Gresik [Tesis]. Surabaya : Universitas Airlangga; 2018.

27. Lestarina, NNW. Theory of planned behavior sebagai upaya peningkatan kepatuhan pada klien diabetes mellitus. Jurnal MKMI. 2018; 14(2):201-207. 